Piotr Benduch*, Krzysztof Butryn*

\title{
Selected Problems of Valuation of Built-Up Real Properties without Considering Their Components
}

\begin{abstract}
The Act of August 21, 1997, on Real Estate Management lays down a series of procedures for which a property appraiser is required to estimate the value of a property built up on the theoretical assumption that the land is undeveloped, thus excluding the components of the property.

Determining the value of such land using a comparative approach methodology has many problems associated with the correct selection of similar properties, especially in the areas of compact urban development and areas for which a local spatial management plan does not apply.

This article points to problems related to determining the value of built-up properties that assume that they are undeveloped land. The procedures for managing real estate that require such a valuation are presented in a synthetic manner. For the selected procedures, the practical difficulties were identified. The authors draw attention to the relevance of the issue in the context of its financial implications, especially in view of the introduction of universal taxation of real estate.
\end{abstract}

Keywords: real estate valuation, land property, components of real properties, valuation survey

Received: 24 July 2017; accepted: 6 February 2018

\footnotetext{
- AGH University of Science and Technology, Faculty of Mining Surveying and Environmental Engineering, Krakow, Poland
} 


\section{Introduction}

In Polish legislation, the basic legal regulation defining the concept of real estate is Article 46 of the Civil Code. According to its record, "Real estate is a part of the Earth's surface constituting a separate object of ownership (land) as well as buildings permanently attached to this land or parts of such buildings if, under special provisions, they constitute an object of ownership separate from the land." It is worth noting that the separation of real properties should be carried out both in legal (ownership) and physical terms (in relation to the land - surveying). The legislation also presents an alternative definition of real estate, contained in the provisions of Art. 24, Section 1 of the Act on Land Registers and Mortgage (the so-called real property in land and mortgage registers): "Real estate is a part of the Earth's surface for which a land and mortgage register has been established." The first civil law definition of real estate is overriding, which is a consequence of the primacy of the civil code in this respect. The above-mentioned civil law definition of real estate implies that three immovable properties may constitute a real property; namely, land, buildings, and parts of buildings (premises).

This study deals with land property. Civil law regulations imply that this type of real property may consist of land (by definition), its components, and its appurtenances.

In the discussed context, land is understood as an area separated from the surface of the Earth by boundaries. It is therefore identified with a single record parcel or with a complex of record parcels. The problem regarding a definition of a record parcel and its amendments over the years has been widely discussed in the national literature $[1,2]$.

An important issue to be discussed in this context is the problem of a definition of components of real properties. This is referred to in Article 47 of the Civil Code, which states that "A component part of a thing cannot be a separate object of ownership and other property rights" (Article 47 §1). In particular $\S 2$ of this article is of key importance: "A component part of a thing is anything that cannot be separated therefrom without damaging or substantially altering the entire thing or without damaging or substantially altering the separated object." The superficies solo cedit rule applies here, whose literal translation is most frequently as follows: "what is on the surface belongs to the land."

Consequently, objects attached to a thing only for temporary use do not constitute its components according to the criterion of the permanent attachment to land (Article 47 §3). The following objects may be considered land components: buildings, non-building facilities, structures and other facilities (e.g., parking), other objects that do not meet the definition of a building (e.g., objects of landscape architecture, wells), still water, trees and other plants, the rights established on a real property (e.g., the right of way), and minerals such as sand, gravel, or peat within the boundaries of a real property. On the other hand, minerals such as shale gas or coal that are the so-called mining property located outside the boundaries of a real property are not considered its components. Similarly, this is the case with thermal brine and thermal waters. Interestingly, components of a real property do not 
include transmission facilities (either above-ground or underground) except when transmission facilities are located within the boundaries of a company's real estate and function as internal networks. They are then treated as part of the real property.

The third group of components is appurtenances. In the light of the civil law, they include movable things necessary to use the main thing (a real property in this case) that are economically (functionally) related. The issue of appurtenances is particularly important for the valuation of industrial estates where there are numerous machines and other equipment permanently attached to a building. They are essential for the proper functioning of the object but, at the same time, cannot be classified as its components. Konowalczuk [3] states that, in the process of valuation, it is important to distinguish between those appurtenances and components whose ownership is obligatorily transferred to the buyer of the land.

The above-discussed conditions demonstrate that developed real properties (as a special type of real estate) can be characterized by significant complexity.

\section{Residual and Raw Value of Land}

The Act of August 21, 1997, on Real Estate Management [4] and its secondary legislation lay down a series of procedures for which a property valuer is obligated to estimate a value of built-up real properties on a theoretical assumption that they are undeveloped land; i.e., without taking into account the components of the real properties. In other words, it is necessary to specify the value of the land only as part of the value of the entire real property in the process of valuation even though the land is actually built-up.

Elaboration on this subject should begin with the presentation of the concept of market value of a built-up property without taking into account its components. According to Arnott [5], two concepts can be distinguished.

The first one is the so-called residual land value. It is determined by estimating the market value of a built-up real property and then subtracting the replacement cost of its components, taking into account the degree of their wear (or in the case of buildings under construction, the degrees of their completion).

Therefore, the value of undeveloped land can be determined in accordance with the following general relationship:

$$
W_{G}=W_{R}-\left(K_{\mathrm{ODTW}}+Z\right)
$$

where:

$W_{G}$ - market value of undeveloped land property,

$W_{R}$ - market value of built-up land property,

$K_{\text {ODTw }}$ - replacement cost of its components, taking into account the degree of their wear/completion,

Z - investor's profit. 
In the process of determining the market value of a built-up real property $\left(W_{R}\right)$, the methodology of a comparative or income approach is used. In order to specify the replacement costs of its components $\left(K_{\text {ОDTW }}\right)$, a cost approach is applied. This demonstrates that, as far as assumptions are concerned, this procedure is consistent with the mixed pricing approach (using the residual method).

In the case of market valuation, some doubts arise as to recognizing the estimated value as market value, because the result of the valuation is, in fact, the result of operations used to determine the replacement value of a real property. The value determined in this way may result in significant divergences in valuations the larger the more complex the character of a built-up real property is. According to Wyatt [6], it should be used only to estimate the approximate value of land; this value will then be verified by independent valuation.

The second concept under consideration is the so-called raw land value. In this approach, the value of the built-up land (without taking into account its components) equals the value of identical undeveloped land. In other words, in the valuation process based on market data, the most probable price for which the land would be sold is sought (with the hypothetical assumption that it was undeveloped). Thus, the assessed value is fully consistent with the assumptions of the market value of the real property. The biggest difficulty associated with valuation using such a methodology is the lack of an adequate quantity of market data [7], especially in highly urbanized areas. For example, it may be extremely difficult to select similar properties to value real estate located in a city center where there is no undeveloped land (land properties have already been urbanized). In Poland, it is the raw value of the land that is estimated for the needs of numerous real estate management processes (which will be discussed later in the paper). In particular, it is recommended to impose a real estate tax ad valorem for the purpose of valuing land. As the authors representing economic centers [7] point out, only defining the value of undeveloped land in terms of its raw land value can result in taxation that meets the criterion of neutrality and guarantees no influence of property holders on economic decisions [8].

\section{Separating Transaction Price for Land from Total Transaction Price of Real Property}

One of the practical problems associated with the valuation of built-up land without taking into account its components is the lack of market data on transactions involving similar undeveloped land properties. The literature provides examples of attempts made to solve this problem by using models designed to separate the price of undeveloped land from the total transaction price of the builtup property. 
A general scheme of such proceedings may be illustrated by the dependence:

$$
C_{T}=C_{T-G}+\sum_{i} C_{T i}
$$

where:

$C_{T}$ - transaction price obtained from a notarial deed or from the Register of Real Estate Prices and Values,

$C_{T-G}$ - separated transaction price of undeveloped land,

$C_{T i}$ - separated transactional prices of real estate components.

In order to implement the general dependence expressed by the equation above, the authors present various methodologies. First of all, advanced statistical models based on the method of least squares [9] should be listed, which allows us to create a model for dividing a transactional price into the prices of individual components (along with an assessment of accuracy). A similar approach is demonstrated in $[10,11]$, where it is suggested to separate trends of the unit value of land and unit value of the usable floor area of a building in the dynamics of the value of a built-up property. Further, Kuryj [12] develops two methods for separating the price of land from the total transaction price of built-up real estate - a simplified method (based on the analysis of the percentage share of prices of buildings in total transaction prices of similar real properties) as well as a cause-and-effect econometric model.

Those mentioned above (and others not mentioned in this paper), similar methodologies that can be classified as a statistical analysis of the market in a comparative approach, are rarely used in practice. Property valuers are more likely to use the other two comparative methodologies - the pairwise comparison and average price adjustment methods. Both methodologies are based on the selection of a set of the most likely similar properties from the respective local market. For some studies (e.g. to secure claims), the methods that belong to the market statistical analysis methodology are frequently excluded.

\section{Real Estate Management Procedures Requiring Determination of Market Value of Built-Up Real Properties without Considering Their Components}

Synthetically selected real estate management processes and procedures that deal with the question of the components of real estate are presented below (Tab. 1). The following section of the paper discusses the practical problems associated with some of them. 
Table 1. Selected real estate management processes and procedures related to separate valuation of land and its components

\begin{tabular}{|c|c|c|}
\hline $\begin{array}{c}\text { Real estate } \\
\text { management } \\
\text { process }\end{array}$ & $\begin{array}{c}\text { Legal } \\
\text { conditions, } \\
\text { standards }\end{array}$ & Arrangements on considering real estate components \\
\hline $\begin{array}{l}\text { Determination } \\
\text { of replacement } \\
\text { value of } \\
\text { a built-up real } \\
\text { property, cost } \\
\text { approach of } \\
\text { valuation }\end{array}$ & $\begin{array}{l}\text { Real Estate } \\
\text { Management } \\
\text { Act } \\
\text { Article 135.2. } \\
\text { Article 153.3. }\end{array}$ & $\begin{array}{l}\text { When determining the replacement value of } \\
\text { a property, the value of the land and of its } \\
\text { components shall be determined separately. } \\
\text { The cost approach determines the value of a property, } \\
\text { assuming that this value corresponds to the cost of } \\
\text { its replacement (less the wear of this property). This } \\
\text { approach determines the cost of land acquisition and } \\
\text { the replacement cost of its components separately }\end{array}$ \\
\hline $\begin{array}{l}\text { Valuation of } \\
\text { land property } \\
\text { lent into } \\
\text { perpetual } \\
\text { usufruct }\end{array}$ & $\begin{array}{l}\text { Ordinance } \\
\text { on real estate } \\
\text { appraisal } \\
\text { and estimate } \\
\text { statement } \\
\S 28.3 \text {. }\end{array}$ & $\begin{array}{l}\text { If the land property lent into perpetual usufruct is } \\
\text { built-up (having determined its value as the subject } \\
\text { of property rights), the value of the land, buildings } \\
\text { (or parts thereof), and other equipment shall be } \\
\text { separated from this value }\end{array}$ \\
\hline $\begin{array}{l}\text { Determining } \\
\text { financial } \\
\text { consequences } \\
\text { of adopting or } \\
\text { changing local } \\
\text { zoning plans }\end{array}$ & $\begin{array}{l}\text { Ordinance } \\
\text { on real estate } \\
\text { appraisal } \\
\text { and estimate } \\
\text { statement } \\
\text { §50.1. } \\
\text { (repealed) }\end{array}$ & $\begin{array}{l}\text { When determining the market value of a property in } \\
\text { order to specify the amount of compensation or fees } \\
\text { referred to in Art. 36, Sections } 3 \text { and } 4 \text { of the Spatial } \\
\text { Planning and Land Development Act of March 27, } \\
2003 \text { (Journal of Laws, No. 80, item 717, and of 2004, } \\
\text { No. 6, Item 41, and No. 141, item 1492), the value } \\
\text { of a property is determined, taking into account its } \\
\text { intended use prior to when the local zoning plan was } \\
\text { adopted or prior to when it was amended as well as its } \\
\text { intended use after the local zoning plan was adopted } \\
\text { or after it was amended. The components of this } \\
\text { property are not taken into consideration }\end{array}$ \\
\hline $\begin{array}{l}\text { Property } \\
\text { valuation } \\
\text { prior to and } \\
\text { after the } \\
\text { construction } \\
\text { of technical } \\
\text { infrastructure }\end{array}$ & $\begin{array}{l}\text { Ordinance } \\
\text { on real estate } \\
\text { appraisal } \\
\text { and estimate } \\
\text { statement } \\
\S 40.1 \text {. }\end{array}$ & $\begin{array}{l}\text { When determining the value of a property prior to the } \\
\text { construction of technical infrastructure and after the } \\
\text { construction of technical infrastructure (in order to } \\
\text { determine the betterment levies referred to in Art. } 107 \\
\text { - obligation to pay betterment levies [Section 1] and } \\
\text { Art. } 146 \text { - determining and amount of betterment levy } \\
\text { [Section } 3 \text { of the act]), the components of this property } \\
\text { are not taken into consideration }\end{array}$ \\
\hline $\begin{array}{l}\text { Real estate } \\
\text { subdivisions - } \\
\text { betterment } \\
\text { levies }\end{array}$ & $\begin{array}{l}\text { Real Estate } \\
\text { Management } \\
\text { Act } \\
\text { Article 98a }\end{array}$ & $\begin{array}{l}\text { The state of a property before subdivision is specified } \\
\text { on the day of issuance of the decision approving the } \\
\text { property subdivision, and the state of a property after } \\
\text { subdivision is specified on the day when the decision } \\
\text { approving the property subdivision became final } \\
\text { (or the judgment on subdivision became final and } \\
\text { binding). The components of this property are not } \\
\text { taken into consideration }\end{array}$ \\
\hline
\end{tabular}


Table 1. cont.

\begin{tabular}{||l|l|l||}
\hline $\begin{array}{l}\text { Valuation of } \\
\text { real estate } \\
\text { located on } \\
\text { mineral } \\
\text { deposits } \\
\text { constituting its } \\
\text { components }\end{array}$ & $\begin{array}{l}\text { Ordinance } \\
\text { on real estate } \\
\text { appraisal } \\
\text { and estimate } \\
\text { statement } \\
\S 47\end{array}$ & $\begin{array}{l}\text { When determining the value of a property located } \\
\text { on mineral deposits constituting components of this } \\
\text { property, its value is determined by taking the value } \\
\text { of the deposit into consideration }\end{array}$ \\
\hline $\begin{array}{l}\text { Universal } \\
\text { property } \\
\text { taxation }\end{array}$ & $\begin{array}{l}\text { Real Estate } \\
\text { Management } \\
\text { Act Article } 165 \\
\text { Article } 167\end{array}$ & $\begin{array}{l}\text { Components of the cadastral value: the cadastral value } \\
\text { of the land is the cadastral value of the land together } \\
\text { with the cadastral value of its components }\end{array}$ \\
\hline $\begin{array}{l}\text { Right-of- } \\
\text { way for } \\
\text { transmission } \\
\text { facilities - } \\
\text { determining } \\
\text { value based } \\
\text { on market } \\
\text { data }\end{array}$ & $\begin{array}{l}\text { National } \\
\text { Standard of } \\
\text { Specialized } \\
\text { Valuation No. } \\
4-\text { Linear } \\
\text { Investments - } \\
\text { right-of-way for } \\
\text { transmission } \\
\text { facilities and } \\
\text { use of property } \\
\text { without } \\
\text { contractual basis }\end{array}$ & $\begin{array}{l}\text { The market value of a right-of-way for transmission } \\
\text { facilities is equal to the difference between the value } \\
\text { of a property encumbered and not encumbered } \\
\text { determined in a comparative approach or income } \\
\text { approach (in particular, encumbrance of a property } \\
\text { with a right-of-way for transmission facilities is } \\
\text { associated with the location of objects that may be } \\
\text { components of this property) }\end{array}$ \\
\hline
\end{tabular}

\section{Determining Financial Consequences of Adopting or Amending Local Zoning Plans}

Under Art. 36 of the Spatial Planning and Land Development Act of March 27, 2003 [13], if, in connection with the adoption of a local zoning plan or its amendment, the value of a property has decreased and the owner or perpetual usufructor disposes of that property, they may demand compensation from the commune, which will be equal to a decrease in property value. If, as a consequence of the adoption of a local zoning plan or its amendment, the value of a property has increased and the owner or perpetual usufructor disposes of that property, the mayor of a commune, county, or a city shall receive a one-off fee specified in that plan determined in percentages to the increased value of the property. Furthermore, [13] explains that a decrease or increase in the value of a real property constitutes "the difference between the value of the property, taking into consideration the land use after the adoption or amendment of the local zoning plan and its value determined prior to the adoption of this plan or actual manner of use of the property prior to its adoption." The legislator does not refer in any way to the problem of components, treating the concept of property value in a general way. 
The issue of the financial consequences of adopting or amending local zoning plans is also referred to in [14]. According to the current (April 2017) wording of Paragraph 51 of the aforementioned act, when determining the actual value of real estate to define financial consequences of adopting or amending local zoning plans, the values of properties representative of each land use in that plan is determined. It is, therefore, evident that there are no arrangements to take into account the components of a built-up property in the valuation procedure.

This issue was referred to in the wording of Paragraph 50, repealed by the Regulation of the Council of Ministers of July 14, 2011 (Journal of Laws No. 165 of 2011, Item 985), which came into force on August 26, 2011. The repealed provision stated unambiguously that, in the valuation process for that specific purpose, components of a property should not be taken into account. A property valuer whose task it is to assess the value of a built-up property for the purpose of determining the financial consequences of adopting or amending local zoning plans currently encounters some ambiguities already at the initial key stage of the work, which includes a correct definition of the subject and scope of the valuation. This problem was repeatedly reported by the professional community of property valuers [15], indicating that a repeal of this paragraph without simultaneous amendments to the Spatial Planning and Land Development Act could result in misunderstandings in property valuation. In the absence of binding regulations, property valuers continue to follow the provisions of Paragraph 50 by not taking real estate components into account in the valuation process. There is no clear legal basis for such a procedure, but it is supported by the case law. In their statement of reasons for case II OSK 1756/06, the Supreme Administrative Court notes that, by failing to take into account the components of a valued real estate both before and after the plan has been adopted or amended, the possibility to determine an increase in the property value as a result of other factors than those prescribed by law is eliminated.

In conclusion, considering the current legislation (where there are no clear regulations on determining the value of real estate for the purpose of establishing the so-called zoning fee), failure to include real estate components in the valuation process may be disputable.

\section{Literal Interpretation of the Provisions of Art. 154 Section 2 and 3 of the Real Estate Management Act}

Pursuant to Art. 154 of the Real Estate Management Act, the intended use of real estate is determined based on the local zoning plan. In the absence of a plan, land use is determined subject to a study of the conditions and directions of spatial development in a commune or planning permit. In the absence of a study or permit, the actual use of a property is taken into account. 
Therefore, the sequence of analyzing zoning documents is as follows:

1. local zoning plan,

2. planning permit (building permit for public purpose investment and decision on land development),

3. study of conditions and directions of spatial development in a commune,

4. actual use of a property.

If the property being valued is subject to a study and a planning permit, first, it is necessary to take into account the planning permit (which is individual and specific), as it sets out conditions for the land development of a particular investment. The actual use of real estate is generally determined on the basis of documentation in the form of reports from the register of land and buildings [16] if the use of a property identified during a site inspection is consistent with the data contained in the register of land and buildings.

The above considerations may be illustrated by the following diagram (Fig. 1).

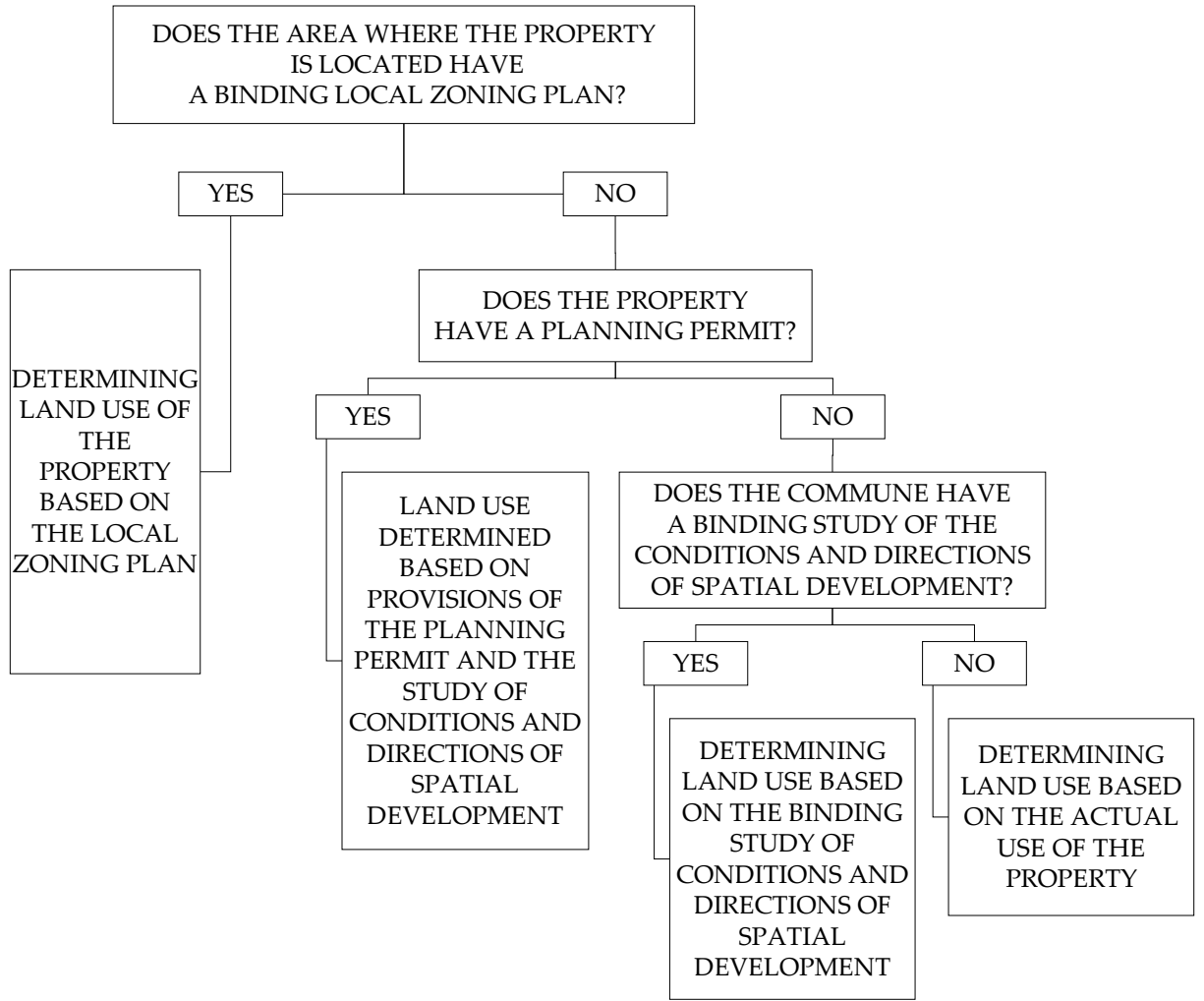

Fig. 1. Sequence of analyzing zoning documents 
Let us consider an example of record parcel No. 1509/12, developed with a single-family residential building (Fig. 2).

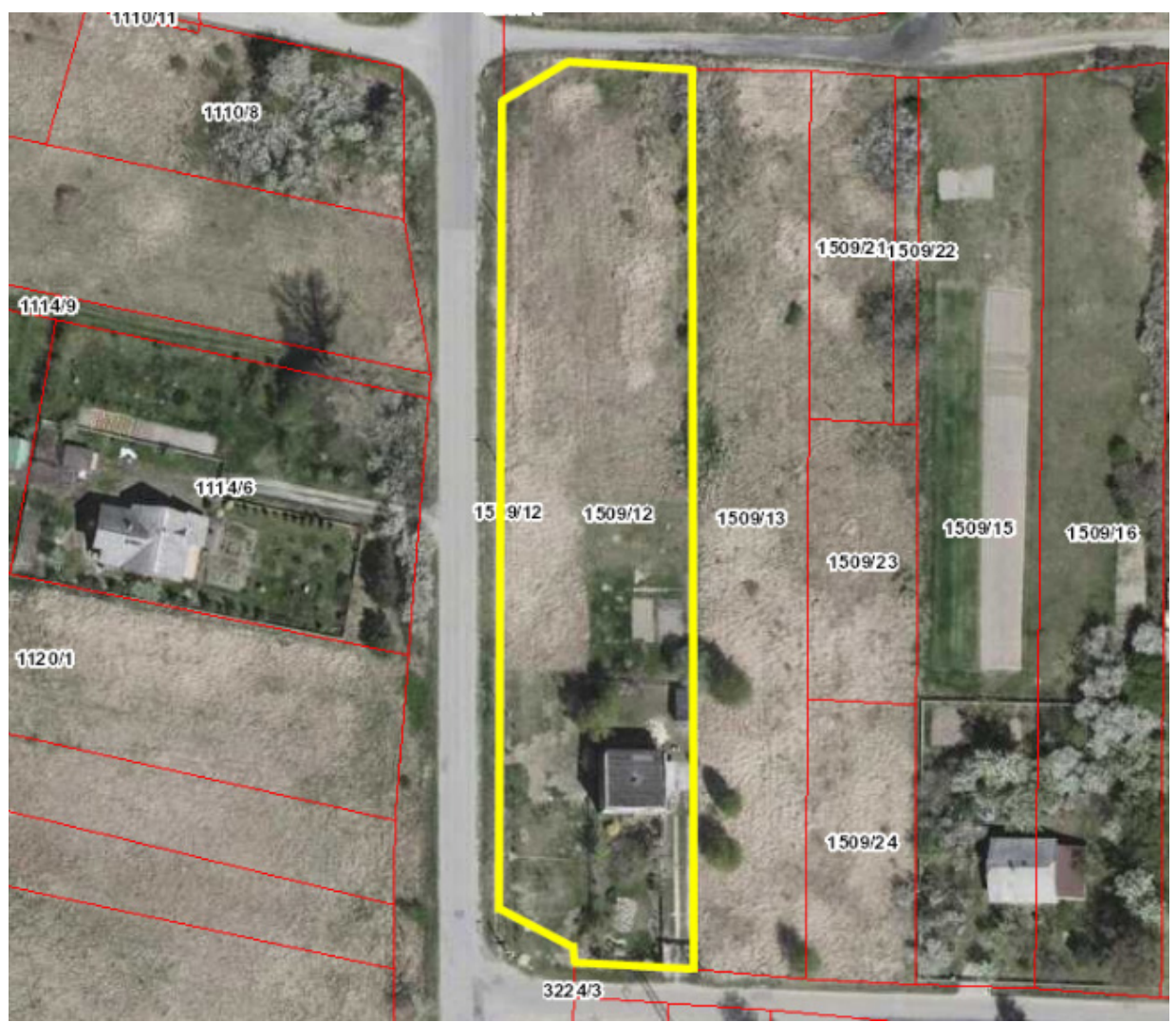

Fig. 2. Course of boundaries of analyzed parcel

Source: http://mapy.geoportal.gov.pl/

According to a letter from the city administration in L(...) (ref: AGGN.6727.72.2016. DS) of July 29, 2016, as of the date of the letter, parcel No. 1509/12 is not covered by the local zoning plan, and according to the directions of spatial development in a commune contained in the "Study of the conditions and directions of spatial development in a commune of $\mathrm{L}(. .$.$) " approved by a resolution of the city council in \mathrm{L}(. .$.$) No.$ IV/30/98 of December 30, 1998, as amended, the parcel is entirely located in the agricultural production zone with the possibility of development related to agricultural and horticultural production, processing, and storage (denoted as 1RPO) (Fig. 3).

According to the study, there is the possibility of development related to agricultural and horticultural production, processing, and storage on the property in question; however, there is no possibility of single-family housing development. 
The owner of such real estate will not apply for a planning permit, since a house is already located there. Of course (theoretically speaking), the owner could have applied for such a permit, especially that the conditions of the neighboring parcels would probably have made it possible to be obtained. However, literal interpretation of Art. 54 of the Real Estate Management Act leads us to the conclusion that the parcel in question cannot be developed for single-family housing (according to the provisions of the study). As a consequence, such properties should be considered for real estate valuation purposes whose intended use is similar; i.e., those with no possibility of housing development, which naturally decreases the value of the property. Properties that are similar to the one being valued and differ in their use are listed below.

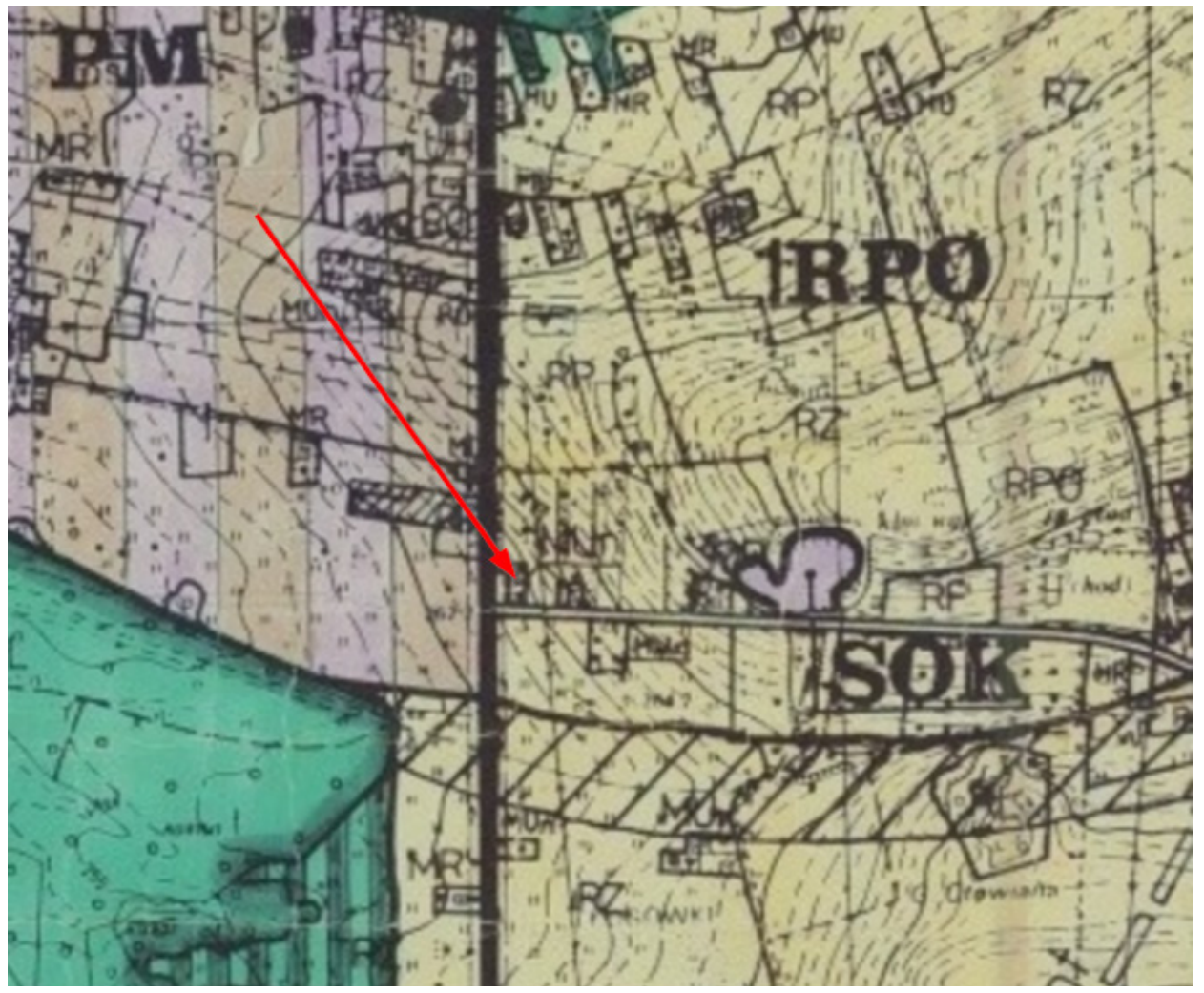

Fig. 3. Fragment of drawing part of study of conditions and directions of spatial development

Source: Public information bulletin of city administration in $\mathrm{L}($...)

Database 1 (Tab. 2) contains properties for which a planning permit has been issued allowing for one-family housing development, whereas Database 2 (Tab. 3) pp contains properties for which no such permit has been issued. 
Table 2. Database of similar properties for which planning permit has been issued

\begin{tabular}{||c|c|c|c|c|c|c||}
\hline No. & District & $\begin{array}{c}\text { Cadastral } \\
\text { unit }\end{array}$ & Land use & $\begin{array}{c}\text { Surface } \\
\text { area of } \\
\text { parcel } \\
{\left[\mathrm{m}^{2}\right]}\end{array}$ & $\begin{array}{c}\text { Transac- } \\
\text { tion price } \\
{[\text { PLN] }}\end{array}$ & $\begin{array}{c}\text { Transac- } \\
\text { tion price } \\
{\left[\text { PLN/m }{ }^{2}\right]}\end{array}$ \\
\hline \hline 1. & $\mathrm{c}(\ldots)$ & $\mathrm{L}(\ldots)$ & Study: RPO + planning permit & 2420 & 91,000 & 37.60 \\
\hline 2. & $\mathrm{c}(\ldots)$ & $\mathrm{L}(\ldots)$ & Study: RPO + planning permit & 3566 & 105,000 & 29.44 \\
\hline 3. & $\mathrm{c}(\ldots)$ & $\mathrm{L}(\ldots)$ & Study: RPO + planning permit & 3661 & 150,000 & 32.18 \\
\hline 4. & $\mathrm{c}(\ldots)$ & $\mathrm{L}(\ldots)$ & Study: RPO + planning permit & 2452 & 58,800 & 40.50 \\
\hline 5. & $\mathrm{c}(\ldots)$ & $\mathrm{L}(\ldots)$ & Study: RPO + planning permit & 2774 & 100,000 & 36.05 \\
\hline 6. & $\mathrm{c}(\ldots)$ & $\mathrm{L}(\ldots)$ & Study: RPO + planning permit & 2056 & 65,895 & 32.05 \\
\hline 7. & $\mathrm{c}(\ldots)$ & $\mathrm{L}(\ldots)$ & Study: RPO + planning permit & 3378 & 80,000 & 23.68 \\
\hline 8. & $\mathrm{c}(\ldots)$ & $\mathrm{L}(\ldots)$ & Study: RPO + planning permit & 2107 & 60,000 & 28.47 \\
\hline 9. & $\mathrm{c}(\ldots)$ & $\mathrm{L}(\ldots)$ & Study: RPO + planning permit & 2172 & 100,000 & 46.04 \\
\hline
\end{tabular}

Table 3. Database of similar properties for which planning permit has not been issued

\begin{tabular}{|c|c|c|c|c|c|c||}
\hline No. & District & $\begin{array}{c}\text { Cadastral } \\
\text { unit }\end{array}$ & Land use & $\begin{array}{c}\text { Surface } \\
\text { area of } \\
\text { parcel } \\
{\left[\mathrm{m}^{2}\right]}\end{array}$ & $\begin{array}{c}\text { Transac- } \\
\text { tion price } \\
{[\text { PLN] }}\end{array}$ & $\begin{array}{c}\text { Transac- } \\
\text { tion price } \\
{\left[\text { PLN/m }{ }^{2}\right]}\end{array}$ \\
\hline \hline 1. & $\mathrm{c}(\ldots)$ & $\mathrm{L}(\ldots)$ & Study: RPO, no planning permit & 1756 & 7498 & 4.27 \\
\hline 2. & $\mathrm{c}(\ldots)$ & $\mathrm{L}(\ldots)$ & Study: RPO, no planning permit & 3967 & 7974 & 2.01 \\
\hline 3. & $\mathrm{c}(\ldots)$ & $\mathrm{L}(\ldots)$ & Study: RPO, no planning permit & 2022 & 5945 & 2.94 \\
\hline 4. & $\mathrm{c}(\ldots)$ & $\mathrm{L}(\ldots)$ & Study: RPO, no planning permit & 4258 & 16,734 & 3.93 \\
\hline 5. & $\mathrm{c}(\ldots)$ & $\mathrm{L}(\ldots)$ & Study: RPO, no planning permit & 1756 & 7498 & 4.27 \\
\hline 6. & $\mathrm{c}(\ldots)$ & $\mathrm{L}(\ldots)$ & Study: RPO, no planning permit & 2834 & 17,996 & 6.35 \\
\hline 7. & $\mathrm{c}(\ldots)$ & $\mathrm{L}(\ldots)$ & Study: RPO, no planning permit & 2334 & 15,008 & 6.43 \\
\hline 8. & $\mathrm{c}(\ldots)$ & $\mathrm{L}(\ldots)$ & Study: RPO, no planning permit & 1870 & 13,090 & 7.00 \\
\hline 9. & $\mathrm{c}(\ldots)$ & $\mathrm{L}(\ldots)$ & Study: RPO, no planning permit & 1910 & 13,466 & 7.05 \\
\hline 10. & $\mathrm{c}(\ldots)$ & $\mathrm{L}(\ldots)$ & Study: RPO, no planning permit & 2646 & 20,004 & 7.56 \\
\hline
\end{tabular}

Even a cursory analysis of the price distribution of similar properties suggests the obvious conclusion that the issuance of a planning permit directly affects the estimated value of a property. In this case, a literal interpretation of the regulations results in the decreased value of the property. This situation is favorable, for exam- 
ple, for transmission operators who seek to minimize the amounts of compensation for the establishment of rights-of-way for their transmission facilities.

A solution could reject the literal interpretation of the legal regulations and, considering each case, the optimal use of a property. Another solution is an auxiliary determination of residual value of land, which is a good approximation of the raw value of land.

\section{Valuation of Properties Located in Downtown Area}

Among the processes listed in Section 4, it is possible to distinguish those for which it is necessary to estimate the value of undeveloped land for built-up properties located in areas of dense housing development; e.g., in urban areas. Such valuations are aimed, first of all, at determining the value of real estate for the purpose of updating annual fees for perpetual usufruct or, in the future, the cadastral value of the real properties.

The valuation of undeveloped real estate located in highly urbanized areas is very problematic mainly due to the shortage of similar real estate transactions, which makes the estimation of the raw value of land extremely difficult. Moreover, in the case of multi-family residential development and atypical buildings, the valuation of the residual value of land is also a nuisance. Algorithms of residual methodology are highly inefficient, especially for the needs of mass property valuation. At the same time, properties located in downtown areas usually have relatively high values; thus, differences in the valuation results of such real estate can have serious financial consequences. The question of the valuation of built-up properties located within a city center constitutes an extremely interesting research problem that the authors intend to deal with in the future.

\section{Summary}

The valuation of built-up real properties without considering the value of their components is a task accompanying numerous real estate valuation and property management procedures.

In this paper, the concepts of real estate and its components as well as appurtenances have been presented in the first place, pointing to the fact that the correct identification of real estate components frequently implies the correctness of the performed valuation. Furthermore, two literary concepts of the value of built-up real estate without considering its components have been described; i.e., the residual and raw value of the land. The authors have also presented methods for separating the price of the land and real estate components from the total transaction price. Then, selected real estate valuation and real estate management procedures were demonstrated, which require the 
valuation of built-up land without its components. Some of them have been discussed in detail; in particular, the issue of the inconsistencies of the legal provisions in the definition of the financial consequences of the adoption or amendment to local zoning plans and the imperfection noted by the authors in the practice related to the literal interpretation of the provisions of Art. 154, Sections 2 and 3 of the Real Estate Management Act.

In most cases, the discussed problem carries or may carry serious financial consequences; therefore, the authors point to the need to improve the legislation in this regard, especially if inconsistency, ambiguity, or even the lack of regulation raises fundamental doubts in determining the financial consequences of adopting or amending local zoning plans.

\section{References}

[1] Hanus P., Hycner R., Kwartnik-Pruc A.: Analiza terminologiczna wybranych problemów katastru i zagadnień pokrewnych. Cz. 1, Działka, granica, nieruchomość. Geodeta: Magazyn Geoinformacyjny, nr 10, 2013, pp. 26-31.

[2] Łuczyński R.: Granice działek w ewidencji gruntów i budynków w aspekcie wymagań wspótczesnego katastru nieruchomości. Przegląd Geodezyjny, nr 2, 2009, pp. 3-6.

[3] Konowalczuk J.: Wycena nieruchomości dla celów kredytowych. Poltext, Warszawa 2014.

[4] Ustawa z dnia 21 sierpnia 1997 r. o gospodarce nieruchomościami. Announced text: Dz.U. 1997, nr 115, poz. 741, consolidatet text: Dz.U. 2015, poz. 1774, with amendments.

[5] Arnott R.: Neutral Property Taxation. Journal of Public Economic Theory, vol. 7 (1), 2005, p. 27.

[6] Wyatt P.: Property Valuation. 2 ${ }^{\text {nd }}$ ed. John Wiley \& Sons, 2013.

[7] Głuszak M., Marona B.: Podatek katastralny. Ekonomiczne uwarunkowania reformy opodatkowania nieruchomości. Poltext, Warszawa 2015.

[8] Tidemann N.: A Tax on Land is Neutral. National Tax Journal, vol. 35, 1982, pp. 109-111.

[9] Czaja J., Parzych P.: Szacowanie rynkowej wartości nieruchomości. Wydawnictwa AGH, Kraków 2015.

[10] Adamczewski Z.: Elementy modelowania matematycznego w wycenie nieruchomości. Oficyna Wydawnicza Politechniki Warszawskiej, Warszawa 2006.

[11] Adamczewski Z., Hopfer A.: Trend udziału gruntu i budynku w wartości nieruchomości zabudowanej. Studia i Materiały Towarzystwa Naukowego Nieruchomości, vol. 16, nr 3, 2008, pp. 19-32.

[12] Kuryj J.: Propozycja metody wydzielenia z ceny nieruchomości zabudowanej wartości zabudowy i wartości gruntu. Wycena - Wartość - Obrót - Zarządzanie Nieruchomościami, t. 3, nr 96, 2011, pp. 21-31. 
[13] Ustawa z dnia 27 marca 2003 r. o planowaniu izagospodarowaniu przestrzennym. Announced text: Dz.U. 2003, nr 80, poz. 717, consolidated text: Dz.U. 2015, poz. 199, 443, 774, 1265, 1434, 1713, 1777, 1830, 1890, with amendments.

[14] Rozporzadzenie Rady Ministrów z dnia 21 września 2004 r. w sprawie wyceny nieruchomości $i$ sporzadzania operatu szacunkowego. Announced text: Dz.U. 2004, 207, poz. 2109, with amendments.

[15] Biuletyn Nr 87, IV kwartał 2011 r. PSRWN Zarząd Główny, Warszawa 2011.

[16] Dąbek J., Nowakowska M., Zamroch P.: Wybrane zagadnienia wyceny nieruchomości a problematyka prawna, ekonomiczna i przestrzenna zwiąana z infrastruktura techniczna. Wydawnictwo Replika, Zakrzewo 2015.

\section{Wybrane problemy szacowania wartości nieruchomości zabudowanych bez uwzględnienia części składowych nieruchomości}

Streszczenie: Przepisy prawa w zakresie gospodarki nieruchomościami określają szereg procedur, na których potrzeby rzeczoznawca majątkowy zobowiązany jest do szacowania wartości nieruchomości zabudowanych przy teoretycznym założeniu, iż stanowią one grunty niezabudowane, tj. bez uwzględniania części składowych nieruchomości. Określenie wartości takich gruntów z wykorzystaniem metodologii podejścia porównawczego przysparza licznych problemów związanych z prawidłowym doborem nieruchomości podobnych, szczególnie w wypadku obszarów o zwartej zabudowie śródmiejskiej oraz obszarów, $\mathrm{w}$ odniesieniu do których nie obowiązuje miejscowy plan zagospodarowania przestrzennego.

Artykuł wskazuje na problemy związane z ustalaniem wartości nieruchomości zabudowanych przy założeniu, że stanowią one grunty niezabudowane. W sposób syntetyczny przedstawiono procedury gospodarowania nieruchomościami wymagające przeprowadzenia takiej wyceny. Wskazano trudności praktyczne przy stosowaniu wybranych procedur. Autorzy zwracają uwagę na istotność omawianego zagadnienia w kontekście jego skutków finansowych, szczególnie

Słowa $\mathrm{w}$ perspektywie wprowadzenia powszechnej taksacji nieruchomości.

kluczowe: $\quad$ wycena nieruchomości, nieruchomość gruntowa, części składowe nieruchomości, operat szacunkowy 